International Journal of English Literature and Social Sciences
Vol-6, Issue-2; Mar-Apr, 2021
Journal Home Page Available: $\underline{\text { https://ijels.com/ }}$
Journal DOI: $10.22161 /$ ijels

\title{
Caste and Reservation in India
}

\section{Soma Mandal}

Academic Researcher, Jadavpur University, Kolkata, India.

Received: 09 Jan 2021; Received in revised form: 06 Mar 2021; Accepted: 26 Mar 2021; Available online: 19 Apr 2021

(C)2021 The Author(s). Published by Infogain Publication. This is an open access article under the CC BY license

(https://creativecommons.org/licenses/by/4.0/).

\begin{abstract}
Reservations in India, specifically, in the context of social and educational backward classes $(S E B C)$ have been undergoing constitutional setbacks in the recent years. The increasing politicization and subsequent echoes of scraping down reservations in appointments and promotions to SC, and STs, sporadic discontinuation of fellowships for socially backward students, absence of accurate data on backlog vacancies, reserved positions vacant in employment, and finally, in most cases underrepresentation in the 49.5-50 per cent quota out of which 15 per cent for SCs, 7.5 per cent to STs and 27 per cent to OBCs that have been earmarked, lays bare the institutional breach in the promise of social justice. Reservation in this context, calls for a renewed perspective on how and why it not only suffers alienation and conflicts from within the minority sections it so represents, but increasingly projects out as exclusive and exclusionary a category to the majority. The paper attempts to project the double bind within which reservation attempts to articulate the voice of the non-represented. The paper further, draws in the recent judicial judgment of the Uttarakhand High Court in matters of promotion, which arguably bear out contradictory responses to reservation, analyzing in the process a decadal shift in the substantive power of reservation that is being increasingly understood to be a threat to the majoritarian class and caste interests.
\end{abstract}

Keywords-Reservations, SC, ST, Supreme Court, judiciary, affirmative, substantive.

\section{INTRODUCTION}

The debate of reservation has been unequivocally political. Dr B. R. Ambedkar's movement and agitation of separate electorates for Dalits and Bahujans in the Poona Pact (1932), access to drinking water services, greater representation in the provincial electorate and in governing institutions of the country, mass mobilization of socially downtrodden sections of the community, and a transformative organization for Dalits, Adivasis, and Bahujans to overcome socially sanctioned inhuman forms of exploitation constituted some of the early socioeconomic conditions and pre-requisites for construction of reservation policies for SC, STs in India.

Ambedkar's epistemic enquiry into early Dalit life was informed by his ontological position within the lower-caste Marathi family. The subsequent forays into the journey of representing the 'caste problem' in India unravelled a social upheaval unimagined in his time, that has traversed a long history of equity movements in the contemporary times. The contribution of Ambedkar in the contemporary discourse on social justice, reservation, democratic distribution and egalitarian relation has been unparalleled. As the sole iconoclastic figure for the downtrodden, untouchable Dalits his lifetime commitment to the rights of the oppressed will remain unchallenged in the coming historical times.

While reservation has been under scathing criticism from upper margins of the society, there has been increasing dialogues on extending reservation to numerous economically poor, social groups that have no previous socio-cultural history of backwardness. Quota-based reservation and pro-reservation policies suffer from this dialectic of caste politics. The discourse on reservation follows two popular attitudes and perception. First, the victimization of SC, STs who are beneficiaries of the reservation policies in ways which either provokes anger, hate or intimidation on the part of upper caste communities, and it is here that the Constitution by an act of Parliament observes the need for SC, ST Prevention of Atrocities Act variously named as SC-ST Act, or POA, 
1989. POA has been further amended in 2015; and invests legal remedy and protection against the commitment of outrageous atrocities on the Dalits. Second, reservation suffers from dilution of the substantive purpose and advocacy for inclusion by the upper caste people within the ambit of economic reservation quota. The problematic lies in the subjective interpretation by the Courts and the state machinery rendering indistinct and inconsequential the revisionist aim of reservation as a social instrument for socially disadvantaged people with histories of oppression.

Recently, 10 per cent reservation has been extended to the economically vulnerable, open caste category (EWS-GEN) whose annual income comes below the income ceiling of 8 lacs or less than 8 hectares land-holding through the 124th Amendment (Bill) in the Lok Sabha on 8 January 2019. The disputed Economically Weaker Section Reservation Bill which went on to become the 103rd Constitutional Amendment Act added clause 6 to Articles 15 and 16 to ensure 10 per cent reservation w.e.f 14 January 2019. The addition of 15(6) and 16 (6) in Bill No. 3 of 2019 in the Gazette of India dated 12 January 2019, as published by Dr G. Narayana Raju (Secretary to the Govt. of India) and Thaawarchand Gehlot (Ministry of Social Justice and Empowerment) states:

1. In article 15 of the Constitution, after clause 5, the following clause shall be inserted, namely:-

'(6) Nothing in this article or sub-clause (g) of clause

(1) of Article 19 or clause (2) of Article 29 shall prevent the State from making, -

a. Any special provision for the advancement of any economically weaker sections of citizens other than the clauses mentioned in clauses (4) and (5); and

b. Any special provision for the advancement of any economically weaker sections of citizens other than the classes mentioned in clauses (4) and (5) in so far as such special provisions relate to their admission to educational institutions including private educational institutions referred to in clause (1) of the article 30 , which in the case of reservation would be in addition to the existing reservations and subject to a maximum of ten per cent of the total seats in each category.

2. In Article 16 of the Constitution, after clause (5), the following clause shall be inserted, namely: -

"(6) Nothing in this article shall prevent the State from making any provision for the reservation of appointments or posts in favour of any economically weaker sections of citizens other than the classes mentioned in clause (4), in addition to the existing reservation and subject to a maximum of ten per cent of the posts in each category."

The EWS-Gen infers via Article 46 of the Directive Principles of State Policy, "the State shall promote with special care the educational and economic interests of the weaker sections of the people, and, in particular, of the Scheduled Castes and the Scheduled Tribes, and shall protect them social justice and all forms of exploitation.

Following this line of argument, one finds that the nomenclature 'weaker sections' have not been expressly defined as economic weakness and there is a vague assumption underlying the 'weaker section' that has not only made the current legislation on EWS possible but also contentious on numerous grounds:

First, economic backwardness does not constitute a special category for reservation in the Constitution as it can be mitigated by robust economic policies. Second, therefore, it follows - economic backwardness although having close interconnections with social and educational backwardness does not constitute a special category for availing reservations since it does not involve generational history of discrimination. Third, EWS-Gen reservation explicitly mentions reservation in private educational institutes which in the case of SC, STs has not been clearly outlined nor implemented. Fourth, any reasonable right to reservation has been enshrined in the Constitution from the standpoint of social injustice on the lower caste by the upper caste Hindus; and fifth, reservation in a broad sense implies safeguarding the interests of the lower caste and minorities from humiliation and indignity by the upper caste. Here, by extending reservation to the EWS-GEN category that comprises of the upper caste open category (Forward Caste), the principle of reservation stands violated as economically poor but upper caste sections of the community can still be found committing caste injustices and intolerance towards lower caste people. Violating the ontological and guiding principle behind reservation while enjoying the privilege and provisions of reservation can be socially detrimental to the integrity of reservation policies. It may even lead to adverse possession of reservation benefits by the upper caste that was primarily targeted to bridge caste hierarchies and mitigate socio-historic violence on lower caste communities.

SC, ST, and OBCs comprise almost 57 per cent of the total population while the General category constitutes 37 per cent. In 2007, NSSO survey put, "the OBC population in the country at 40.94 per cent, the SC population at 19.59 per cent, ST at 8.63 per cent and the rest at 30.83 per cent. In the roaster on the reservation, SC reservation stands at 15 per cent, ST at 7.5 per cent, and OBC at 27 per cent making up almost 49.5 per cent of the reservation quota on 
69.16 per cent of the total SC, ST, OBC population (Backward Caste). By further adding EWS at 10 percent, the percentage of reserved quota goes over and above the 50 per cent reservation limit proposed in the Indra Sawhney vs Union of India judgement in 1992, eventually taking the reservation cap at 59.5 per cent. That leaves 20 per cent of the population to still have access to 40 percentages of seats in higher education and employment opportunities. The hue and cry over anti-reservation simply cannot be understood given that forward castes already have access to 40 per cent of the share in educational and employment systems.

Although reservation has been guaranteed by the Constitution for lower castes, the actual scenario is quite different. Continued lack of transparency in filling up of SC, ST positions, blocking seats meant for SC, ST communities, not fulfilling the 50 per cent quota for lower castes as a mandatory social duty, creating a backlog in recruitment to government services, political and casteist interference in decision-making and administrative functions, and finally, failing to make the reservation a time-bound constitutional mechanism for speeding up development for the lower caste have cut short the goal of transformative possibility that inheres in the concept of reservation. This is not critiqued as sufficient explanations are provided by the upper caste management bodies for preventing the lower caste to occupy educational and salaried work, often arguing 'lack of merit', 'better open category candidates', ‘concern for compromise on efficiency', 'reserves the right to not fill up', 'unsuitability', 'non-availability of candidate', 'poor quality' and so on, to vindicate and appropriate the discourse of reservation for the benefit of upper-caste and upper-class communitarians.

The contentious EWS Act has thus, raised the storm around the debate on the reservation by providing inclusion and incorporation of economically weak sections. Social and educational backwardness constitute two intersectional forms of inequality - the trajectory of historically backward attributes associated with a community and second, the ideology behind the construction of such backwardness associated with the community over a significant period. EWS-GEN has no underlying attribute of historical injustice in discrimination.

Caste in the South Asian context has a complex genealogy and bio-political evolution. Hegemonic control of the upper caste societies gradually expanded from owning scriptural and brahmanic knowledge production towards administrative and governmental control of the economy, labour, capital and production. In this regard, in a report by Saurabh Gupta (HT), according to the World Inequality
Database study by Thomas Piketty and by author Nitin Kumar Bharti, the current "wealth share of the rich - top 10 per cent of the population has risen from 45 per cent in 1981 to 68 per cent in 2012 (a steep 23 per cent rise), with 50 per cent Brahmins, 31 per cent Rajputs, 44 per cent Bania and 57 per cent Kayastha falling in the richest class. Only 5 per cent ST, 10 per cent SC, 16 per cent OBC, and 17 per cent Muslims fall in the richest category.

The Socio-Economic and Caste Census (2011) first recognized the intersectionality of poverty, caste, minority and religion having a vicious impact on lives of the lower caste, marginalized minority rather than simply economic poverty as a standard of judgement for 'weakness' mentioned in the Directive Principles of State Policy. It was the first of its kind to see poverty having a sociohistoric context with caste and sought to quantify reports on the current status of lower caste development in India However, the 2021 SECC that will take off on 2 Oct 2020 would probably exclude the category of caste to classify households based on income and development. The new pilot SECC has created much tension within the rural SC, ST, OBC households, as comprehensive development indicate not just housing facility but a wide-ranging evaluation of other parameters also.

Caste-based reservation has been only a recent Constitutional intervention for pulling the reign on social crimes perpetrated by India's privileged rich or even economically poor upper caste people on lower caste communities. An economic categorisation of inequality cannot endorse reservation as the favoured route as arguments lodged in favour of such rejection can simply be regarded as the failure of a neo-liberal capitalist state that has been unable to provide equal and egalitarian opportunities of work, education and opportunity. If poverty needs reservation for eradication, then every global hunger movements that recognized poverty as an inhibiting phenomenon would have regarded global reservation as the method for improving the economically weak.

\section{DIALECTIC OF RESERVATION}

The contradiction and dialectic of anti-reservation and proreservation dialogues in the context of reservation on one hand, villanises the category of reservation-holders while on the other, purposely tries to seek possibilities of inclusion within the discourse. Does reservation guarantee representation to the non-represented, lower caste or does it suffer from intra-sectarian caste politics existing within lower caste communities? How does the State perform the function of the reservation? Further, in what ways reservation is appropriated, claimed and instituted for 
pushing on anti-reservation sentiments against lower caste reservation beneficiaries. Finally, how a comparative study of recently developing lower caste groups can be a standard of judgement given the demand the upper castes have been making for quite some time now - the need to impose creamy layer on the rich SC, STs and the need to remove them from the reservation. Given that development index for SC, STs are way below the average level, how can the assertion that rich SC, STs when they are perhaps, first-generation or second-generation beneficiaries be sufficiently called as rich? And finally, how one can possibly anticipate and resist such assaults on the reservation policies given the majoritarian interests on the reservation.

The steady infiltration and dilution of reservation policies compounded by the disproportionate distribution of cultural resources by the state for the socially and educationally backward classes, tall talks on meritocracy and administrative efficiency, reservation revision, adequate representation of lower-caste and minorities, and seventy years progress report run counter to the argument against which the logic of reservation is posited. The paper, therefore, asserts the continued relevance of reservation for recognizing the constitutional rights of backward classes in matters of education, appointment and promotion in services. Recognizing the historical context that informed the Constitutional prerogative of reservation for the lower caste, it argues that reservation is neither a moral compulsion nor a social charitable function of the State. The founding vision on which reservation has been delineated in the Constitution by Ambekar and which was substantiated on three grounds include - breaking the system of hierarchical caste structure and castemonopolisation (Omvedt 1990), combating exploitation, recognizing the rights of lower castes, and finally bringing in parity and equity in human relationships.

Reservation has responded to this dialectic of nonacceptance and acceptance within a continuum of unbridled possibilities. It has been critiqued, stigmatized, alienated, embraced, and appropriated by the privileged class people. The paradigm of reservation has been quite heuristic in nature that has accommodated the shifting locations of its beneficiaries and those outside it. The recent history of the reservation, spanning 70 years since its inception, has stood the test of numerous legislation, amendments and assaults by the privileged caste, brahminical majority. Reservation is thus not without critique by members of both lower caste and upper caste which in the process has made it easier for the upper caste Brahmins to co-opt the narrative of reservation for sections of the upper caste. The recent Jat and Gurjar agitation in North India testifies to this paradoxicality that inheres in reservation, where it is at the same time countered and encountered, violated and disabused making reservation an enticing field of study in social engineering.

\section{RECENT JUDICIAL VERDICT ON RESERVATION}

In the recent Mukesh Kumar \& Anr. vs The State of Uttarakhand \& Ors. judgement, reservation in promotion to SC, STs have been banned by the Supreme Court on 7 Feb 2020. The judgement declared by justices L. Nageswara Rao, and Hemant Gupta observed, "No mandamus can be issued by the Court directing the state government to provide reservations", "no fundamental right inheres in an individual to claim reservation in promotions", "it is settled law the state cannot be directed to provide reservations for appointment in public posts," and "the state is not bound to make reservation for $\mathrm{SCs} / \mathrm{ST}$ in matters of promotions."

The verdict is in the light of the writ petition by Vinod Kumar and three others belonging to the scheduled castes against the Uttarakhand government not implementing the reservation quota in promotions in the posts of Assistant Engineer (Civil) in Public Works Department, Government of Uttarakhand. The petition had been filed in 2011. The High Court observed in its judgement on 1 April 2019, "it is not necessary for the state government to collect quantifiable data regarding the representation of Scheduled Castes and Scheduled Tribes in State services or regarding their backwardness before providing reservation in their favour in promotion" in the light of the verdict in Jarnail Singh (supra) and as stated in the $M$. Nagaraja case.

The verdict was later overruled and reversed in Uttarakhand High Court in 2019. It was challenged in the Supreme Court which declared in February 2020, "There is no fundamental right to claim reservation in appointments or promotion to public posts. This has created confusion regarding whether reservation will cease to be a constitutional prerogative for the lower caste communities. Mr Kapil Sibal, Mr Dushyant Dave and Mr Colin Golsalves learned senior counsel and Dr K. S. Chauhan, learned counsel who appeared for reserved category employees submitted, "The state cannot refuse to collect quantifiable data regarding the adequacy or inadequacy of representation of the Scheduled castes and Scheduled tribes in public services. They submitted that there is an obligation on the State to provide reservations in promotions for the upliftment of the members of the Scheduled castes and Scheduled tribes as mandated by article 16, clause (4-A) of the constitution of India. The right to equality of persons belonging to scheduled castes 
and scheduled tribes cannot be defeated by the State Government by not discharging its constitutional obligation of implementing article 15 (4) and 16 (4-A)." Given the above argument, it is important to read the content of Article 15, 16 and Article 29 (2) given in the Constitution:

"15. Prohibition of discrimination on grounds of religion, race, caste, sex or place of birth.-

(1) The State shall not discriminate against any citizen on grounds only of religion, race, caste, sex, place of birth or any of them.

(2) No citizen shall, on grounds only of religion, race, caste, sex, place of birth or any of them, be subject to any disability, liability, restriction or condition with regard to(a) access to shops, public restaurants, hotels and places of public entertainment; or $b$ ) the use of wells, tanks, bathing ghats, roads and places of public resort maintained wholly or partly out of State funds or dedicated to the use of the general public.

(3) Nothing in this article shall prevent the State from making any special provision for women and children.

(4) Nothing in this article or in clause (2) of Article 29 shall prevent the State from making any special provision for the advancement of any socially or educationally backward classes of citizens or for the Scheduled Castes and the Scheduled Tribes.

(16) Equality of opportunity in matters of public employment. clause: (1) There shall be equality of opportunity for all citizens in matters relating to employment or appointment to any office under the State.

(2) No citizen shall, on grounds only of religion, race, caste, sex, descent, place of birth, residence or any of them, be ineligible for, or discriminated against in respect of, any employment or office under the State.

(3) .....(4) Nothing in this article shall prevent the State from making any provision for the reservation of appointments or posts in favour of any backward class of citizens which, in the opinion of the State, is not adequately represented in the services under the State.

Article 29 (2), prohibits denial of admission to any citizen 'into any educational institution maintained by the State or receiving aid out of State funds on grounds only of religion, race, caste, language or any of them'" under 'Cultural and Educational Rights.'

The committee by the learned counsels for reserved employees, therefore, found the claim by the Uttarakhand Government false and fabricated as "there is inadequate representation of the Scheduled Castes and Scheduled Tribes in the government services in the state of
Uttarakhand. It was contended by the learned counsel that the state government was duty-bound to provide reservation on the basis of the data that was collected by the committee."

The verdict, therefore, stands as a clear exception to the set precedent and due process of law which should have observed the jurisdiction of reservation for the lower castes as a constitutional duty defined in the basic structure of the constitution. Articles 15(4) and 16(4), 16(4-A) are not just enabling provisions but fundamental rights to equality guaranteed under Part III of the Constitution. By allowing the State to exercise free will in matters relating to reservation of backward classes in appointments and promotions, it has left social justice at the discretionary power of the states. The arbitrary discretion of rejecting reservation in appointment and promotion to SC, STs and by allowing de-reservation in the case of Mukesh Singh judgement, it has furthered manipulation and misuse of the reservation provision. Point 8.1 states, "for reservation in non-technical and quasi-technical posts, every effort should be made to recruit a candidate of the reserved category and de-reservation in such vacancies proposed/made only when such a course is inescapable. (Chapter 11, 194) Denying promotion to reserved category employees and deciding matters in the appointment on general criteria reflects the savarnisation of institution and institutionalisation of savarna-led violence on the historically wronged. Although reservation is not inviolable, the absolute necessity to make it a nonnegotiable and unassailable provision under Article 21 has been proposed by the backward classes in this regard.

The verdict is significant as it reflects the erosion of equality, and constitutional morality to be achieved via reservation through Articles 14-18, 29, 46, 341-342, and 335 for the historically backward, caste groups. It has greatly diluted the right to not discriminate against Scheduled Caste, Scheduled Tribes and Other Backward Classes. Preventing promotion to the reserved category employees belonging to the backward caste (SC), thereby, constitutes an act of discrimination by the State.

\section{CASES CITED}

[1] Vinod Prakash Nautiyal vs State of Uttarakhand (2012)

[2] Mukesh Kumar \& Anr. Versus The State of Uttarakhand \& Ors (2020) : WP(Civil) 1226 of 2020

[3] Indra Sawhney Etc. vs Union Of India And Others, Etc. (1992): AIR 1993 SC 477, 1992 Supp 2 SCR 454 https://indiankanoon.org/doc/1363234/

[4] M.Nagaraj \& Others vs Union Of India \& Others (2006) :WP (Civil) 61 of 2002

\section{REFERENCES}


[1] Singh, Mahendra P.(1994): Are Articles 15(4) and 16(4) Fundamental Right? Journal of SCC (3) https://www.ebc-india.com/lawyer/articles/94v3a2.html

[2] Gupta, Saurabh.(2018).Study throws light on rising wealth \& consumption inequality in India https://m.economictimes.com/news/economy/finance/study -throws-light-on-rising-wealth-consumption-inequality-inindia/articleshow/67019490.cms

[3] Santoshi, Neeraj. (2019).HC quashes Uttarakhand's 2012 order to stop quota in promotion. https://www.hindustantimes.com/dehradun/hc-quashesuttarakhand-s-2012-order-to-stop-quota-inpromotion/story-rXB8X5VdxYFUqYGgTH5zkO.html

[4] EPW Editorial. (2020). Supreme Court Judgment on Reservations, Economic and Political Weekly, 55 (7) https://www.epw.in/journal/2020/7/editorials/supremecourt-judgment-reservations.html

[5] EPW Editorial. (2003).'Reservations: Shrinking Pie'. Economic and Political Weekly, 38 (27) https://www.epw.in/journal/2003/27/editorials/reservations -shrinking-pie.html

[6] Das, Bhagwan.(2000). Moments in a History of Reservations Economic and Political Weekly, 35(43-44) https://www.epw.in/journal/2000/43-44/review-womensstudies-review-issues-specials/moments-historyreservations.html

[7] Omvedt, Gail.(1990) 'Twice-Born' Riot against Democracy Economic and Political Weekly, 25 (39) https://www.epw.in/journal/1990/39/perspectives/twiceborn-riot-against-democracy.html

[8] Upadhyay, Vineet. (2020): Uttarakhand bans reservation in promotion for govt services, 18 March 2020. https://www.newindianexpress.com/nation/2020/mar/18/utt arakhand-bans-reservation-in-promotion-for-govt-services2118420.html

\section{GOVERNMENT OF INDIA REPORTS CITED}

[1] India: Ministry of Social Justice and Empowerment: Annual Report, New Delhi (2019

www.socialjustice.nic.in

[2] India: Ministry of Rural Development: Socio-Economic Caste Census 2011 https://secc.gov.in

[3] Gazette of India: Ministry of Law: $124^{\text {th }}$ Amendment Bill, no. 3 of 2019 www.egazette.nic.in

[4] India: Ministry of Law and Justice: The Scheduled Caste and Scheduled Tribes (Prevention of Atrocities) Act, 33 of 1989

https://legislative.gov.in 